\title{
Frivillige organisationers resocialiserende arbejde i Kriminalforsorgens institutioner $^{1}$
}

Annette Olesen, ph.d., lektor Aalborg Universitet og

Anders Brinck Rosenholm, cand. scient. soc. i kriminologi

\begin{abstract}
Outsourcing in the criminal justice system is experiencing growth in the not-for-profit sector in many Western countries. There is, however, no indication of this trend in the Danish Prison and Probation Service. On the contrary, the collaboration between the penal voluntary sector and the Danish Prison and Probation Service is not formalised and knowledge about the penal voluntary sector in Denmark is scarce. This article uses original empirical data to map out the delivery of rehabilitative programmes by the penal voluntary organisations within prison and probation facilities. It also addresses the challenges and potentials of the informal collaboration between the Danish Prison and Probation Service and the penal voluntary sector.
\end{abstract}

\section{Keywords}

Rehabilitation, penal voluntary sector, prison and probation, informal collaboration Resocialisering, frivillighedssektor, Kriminalforsorg, ikke-formaliseret samarbejde

\section{Indledning}

En kortlægning af frivillighedssektoren i den danske Kriminalforsorg er ikke kun interessant, fordi det er første gang, vi får et reelt overblik over disse bidragsydere og deres samarbejder. Det er også interessant, fordi forholdene i de danske fængsler og arresthuse er alarmerende og vidner om, at resocialiserende initiativer bliver nedprioriteret på bekostning af sikkerhed og kontrol.

Vilkårene for straffuldbyrdelse har ændret sig i takt med, at et mere restriktivt kriminalpolitisk paradigme har vundet indpas og resulteret i strengere straffe og en hårdere linje over for bestemte kriminelle grupper. Det har betydet, at Kriminalforsorgens dobbeltfunktion som vogtere af både straffuldbyrdelse og resocialisering gradvist er blevet sværere at balancere.

1. Title in English: Voluntary organisations' rehabilitative work in the Danish Prison and Probation Service 
Behovet for at hjælpe eller påvirke den dømte til at leve en kriminalitetsfri tilværelse bliver udfordret af stigende sikkerhedshensyn i en Kriminalforsorg, der er presset af dårligt arbejdsmiljø, herunder personalemangel, personaleflytninger og massivt overarbejde, højt sygefravær, mange PTSD-diagnoser blandt fængselsbetjente samt overbelægning i arresthuse og fængsler (Larsen et al.; Fængselsforbundet). Det store pres på personalegruppen giver mindre tid til relationsarbejde, hvilket ellers betragtes som en grundsten i det resocialiserende arbejde og den dynamiske sikkerhed.

Selvom fængslerne i mange vestlige lande på systematisk vis har outsourcet resocialiserende initiativer til frivillighedssektoren (Tomczak, 2017a), og til trods for et øget politisk fokus på samspil mellem den offentlige og den frivillige sektor i form af 'samskabelse' og offentlig-frivillige partnerskaber i Danmark (Henriksen et al., 2004, 2015), så har vi ikke kunnet udlede, at der foreligger initiativer, der understøtter nye formaliserede samarbejder i Kriminalforsorgen. Det ændrer dog ikke på, at mange frivillige organisationer hver dag bidrager til resocialiseringen af indsatte/prøveløsladte, vi ved bare ganske lidt om, hvem de er, hvad de bidrager med, og hvordan samarbejdet foregår. Formålet med denne artikel er derfor at kortlægge frivillighedssektorens omfang og bidrag til den danske Kriminalforsorg samt identificere potentialer og udfordringer i samarbejdet mellem de frivillige organisationer og Kriminalforsorgens institutioner. Artiklen består af tre hovedafsnit. Først redegøres der for data og metodetilgang, dernæst behandles uddrag af relevant international forskning, og slutteligt præsenteres de analytiske fund efterfulgt af afrundende bemærkninger.

\section{Data og metode}

Det empiriske materiale som nærværende studie er baseret på, består af 38 interviews. Heraf er 15 med ansatte i Kriminalforsorgen (i det følgende KF-ansatte), som repræsenterer både fængsler, arresthuse, pensioner, KiF-afdelinger, områdekontorer og Direktoratet. Flere af de ansatte havde kombinerede stillinger på pensioner, fængsler og områdekontorer, og mange af dem havde både indsigt i administration og praksis. Af de $15 \mathrm{KF}$-ansatte besvarede 14 et opfølgende spørgeskema. 16 interviews blev afholdt med ledere, projektledere og projektkoordinatorer fra frivillige organisationer (i det følgende frivillig-ansvarlige), og 7 interviews blev afholdt med ledere af delvis private/frivillige organisationer, disse bliver ikke citeret i nærværende studie. Organisationerne bidrager med resocialiserende programmer i Kriminalforsorgens institutioner. Disse programmer er i studiet defineret som ydelser eller aktiviteter udført af frivillige, der har til hensigt at understøtte "a change for the better" (Robinson og Crow, side 3) hos indsatte og/eller prøveløsladte. Interviewene varede 30-60 minutter. De blev udført over telefon som semistrukturerede 
interviews efter en tematisk opdelt spørgeguide. Tilgangen til kodningen har ligeledes været tematisk (Gibbs).

Adgang til feltet skete via en landsdækkende frivillig organisation, der virkede som gatekeeper til relevante KF-ansatte, som varetog koordineringsopgaver med frivillige organisationer. Under interviewene med de KF-ansatte blev de bl.a. bedt om at nævne, de frivillige organisationer de kendte, der arbejdede med indsatte og prøveløsladte. I et opfølgende spørgeskema, fik de efter egen betænkningstid mulighed for at tilføje eller uddybe svar i forhold til de organisationer, som de havde kendskab til. Derefter interviewede vi de frivillig-ansvarlige fra de omtalte organisationer, der kørte programmer i Kriminalforsorgens institutioner. Snowball-sampling blev anvendt til at identificere øvrige relevante organisationer og KF-ansatte.

Det bør nævnes, at der kan være en bias blandt interviewpersonerne i retning af en mere positiv holdning til ens samarbejdspartner. Det kan formodes, at de KF-ansatte, som har indgående kendskab til resocialisering og samarbejdet med de frivillige, også ser mere positivt på selvsamme, end andre personalegrupper. Tilsvarende kan det formodes, at ledere i de frivillige organisationer værner om deres samarbejde med Kriminalforsorgen og modererer deres udtalelser derefter, hvilket frivillige uden ledelsesansvar ikke ville være tynget af.

I det kommende afsnit vil vi inddrage internationale studier til at belyse potentialer og udfordringer, affødt af frivillighedssektorens resocialiserende programmer i straffesystemet.

\section{Baggrund}

Vi ved ganske lidt om den frivillige sektors indvirkning på arbejdet i straffesystemet i de nordiske lande (se dog Abrams et al.; Helminen og Mills; Helminen), men international forskning viser, at frivilliges arbejde i fx fængsler er omfattende. Litteraturen viser dog også, at bidraget af dette arbejde bliver betragtet ganske forskelligt (Tomczak, 2017b). Nogle belyser, at frivillige har en positiv indvirkning på de indsatte (se fx Lippke; Lewis et al.; Cohen, 2009), idet programmer udbudt af frivillige bl.a. bryder med ensomhed og det høje alarmberedskab, der gennemsyrer fængselsinstitutionen. Foruden at være et tiltrængt frisk pust til livet bag tremmer, så skaber de frivillige også et rum, hvor etableringen af pro-sociale relationer kan finde sted. Sådanne støttende initiativer bidrager ikke blot positivt til den enkeltes afsoning, men understøtter også et godt miljø i fængslet mere generelt (se fx Duwe og Johnson; Tomczak og Albertson). Andre studier belyser, hvordan frivillighedssektorens programvirksomhed udøver velmenende tvang eller 'power of care' over de indsatte, som bidrager til at finmaske strafferegimet via en ekstra dimension af kontrol (se fx Cohen 1985; Armstrong). 
Selvom frivilliges arbejde i fængslerne overordnet understøtter mange positive elementer, og i mange tilfælde fungerer godt (Mills et al., 2011, 2012), så er det ikke desto mindre svært at sikre et gnidningsfrit samarbejde mellem to ulige aktører, hvor de frivillige står som udefrakommende, der går ind på fængselspersonalets arbejdsplads og tilkender sig retten til at varetage specifikke opgaver, som oftest har et resocialiserende sigte og bygger på en eller anden form for relationsarbejde. Forskning på området har da også belyst, hvordan såkaldt 'institutional inconvenience' (Mills et al., 2012) afstedkommer både logistiske og ideologiske uoverensstemmelser mellem fængselspersonalet og de frivillige. Disse uoverensstemmelser afspejler, hvordan fængselspersonalet i traditionel forstand er trænet i at fokusere på straffuldbyrdelse, sikkerhed og kontrol, hvorimod de frivilliges fokus snarere er rettet mod individet og resocialisering (Mills et al., 2011; Maguire; Tomczak, 2017a). I relation hertil finder Neuberger (2009), at samarbejdsvanskeligheder ofte opstår i risikobetonede situationer, hvor fagprofessionelt personale skal efterleve retlige foranstaltninger. Eksempler fra empirien viser, hvordan frivillige traditionelt blev betragtet som naive og idealistiske (Neuberger), og værende i ledtog med de indsatte samt opildne til fjendskab mellem indsat og ansat (Hucklesby og Worrall). Derudover blev kvaliteten af de frivilliges arbejde også betvivlet (Neuberger), især arbejdet, udført af frivillige fra mindre velgørenhedsorganisationer, blev vurderet som amatøragtigt og disse frivilliges tilgang til de indsatte som værende på kanten med sikkerhedskravene (Mills et al., 2012). Hertil skal nævnes, at nogle blandt fængselspersonalet også betragter frivillighedssektoren som en konkurrent, der udfordrer dem på deres faglighed (Liebling et al.), og fratager dem især de mere kreative arbejdsopgaver (Bryans el al.). Studier belyser da også, at nogle frivillige møder fængselspersonale, der modsætter sig deres arbejde, fordi det enten strider mod deres egen forståelse af, hvad straffen bør indebære, hvordan sikkerhedskravene bør efterleves, eller fordi de ganske enkelt ikke har tiden til at understøtte samarbejdet tilstrækkeligt (Mills et al., 2011, 2012). Samarbejdet mellem frivillighedssektoren og fængslerne varierer gerne fra institution til institution og i nogle tilfælde fra afdeling til afdeling, hvorfor de frivillige på en og samme tid kan optage roller som partnere, gæster og konkurrenter (Mills et al., 2012).

I de følgende afsnit vil de analytiske fund blive præsenteret. Analysen indledes med et beskrivende afsnit og afsluttes med nogle afrundende bemærkninger.

\section{Resocialiserende arbejde i Kriminalforsorgen}

Kriminalforsorgen skal »støtte og motivere den dømte til gennem personlig, social, arbejds- og uddannelsesmæssig udvikling at leve en kriminalitetsfri tilværelse« (Direktoratet for Kriminalforsorgen). Det resocialiserende arbejde består bl.a. i at hjælpe den indsatte med at etablere en så normal hverdag 
som muligt under afsoningen, hvor den indsatte selv står for madlavning og rengøring og er beskæftiget med arbejde, uddannelse eller anden godkendt aktivitet såsom behandling. Kriminalforsorgen tilbyder behandling mod alkohol- og stofmisbrug og kører på nuværende tidspunkt seks godkendte kognitive programmer. ${ }^{2}$ Den indsatte skal også tilbydes at deltage i fritidsaktiviteter. Disse kan bestå af sport, hobbyaktiviteter eller biblioteksbesøg. ${ }^{3}$ Det har ikke været muligt at afdække, hvorvidt indsatte har krav på et vist omfang af fritidsaktiviteter, og sådanne aktiviteter samt Kriminalforsorgens programvirksomhed er der ifølge de interviewede ikke - eller kun i yderst begrænset omfang - kapacitet til at gennemføre på nuværende tidspunkt. Kriminalforsorgen har også pligt til at støtte og hjælpe de indsatte ved at tilbyde en fast modtagelsesprocedure, hvor Kriminalforsorgen bl.a. afdækker den indsattes behov, udfordringer og kompetencer, og afdækker, hvorvidt der er behov for underretning og kontakt til andre myndigheder (i så fald skal myndighedssamarbejde og overlevering finde sted). Myndighedssamarbejdet kan fortsætte under hele indsættelsen, særligt hvis denne er af kort varighed (Kriminalforsorgen). Snarest efter indsættelsen skal der udarbejdes en handleplan for indsatte, der afsoner en fængselsstraf på mere end fire måneder, eller vis alder, etnisk baggrund eller forsorgsmæssige forhold er indbefattet af pligten hertil. Det er Kriminalforsorgens pligt at koordinere handleplaner med kommunerne jf. handleplanscirkulæret (se også Ramsbøl og Rasmussen). Der er etableret samarbejdsaftaler om løsladelsesarbejdet mellem Kriminalforsorgen og samtlige af landets kommuner, og KiF udmønter desuden en mentorordning, som kan virke som en støttefunktion i udslusnings- og/ eller tilsynsperioden. Selvom de ovenfor beskrevne rammer og intentioner er gode, og der er mange velmenende medarbejdere i både Kriminalforsorgen og løsladelseskommunerne, så er handleplansarbejdet og det koordinerende samarbejde blevet mødt med en del kritik og udstillet som en meget svær øvelse (Rönneling \& Lund-Sørensen 2014, Rönneling et al. 2013, Rigsrevisionen 2011, Storgaard et al. 2014, Berger et al.).

\section{De frivillige organisationer i Kriminalforsorgen}

Foruden den støtte og hjælp, som Kriminalforsorgen er forpligtiget til at udøve overfor de indsatte, så er der også en gruppe af frivillige organisationer, der bidrager til det resocialiserende arbejde i Kriminalforsorgens institutioner. Disse organisationer kan ikke beskrives som en homogen gruppe. Der findes flere relativt store, veletablerede programmer som fx Røde Kors' Besøgstjenesten og Primus Motor, Den Social Retshjælps Fonds Fængselsrejsehold

2. https://www.kriminalforsorgen.dk/straf/faengsel/afsoning-af-faengselsdom/behandling/

3. https://www.kriminalforsorgen.dk/straf/faengsel/afsoning-af-faengselsdom/hverdag-i-faengslet/ 
og Cafe Exits Mentorprogram. Dertil kommer fx den Katolske Kirke og Cafe Exits Kvindeklub, som dækker et mindre geografisk område. Organisationen SAVN opkvalificerer i nogle tilfælde fængselspersonale til at køre specifikke programmer, og Cafe Exit har inkluderet fængselspersonale i deres frivillighedsskare. Det er disse større organisationer, som de KF-ansatte oftest kender til og forholder sig til, når de taler om frivilligt arbejde i Kriminalforsorgens institutioner. Der findes også programmer, som fx KRIM Retshjælp fængselshold, der har udgående aktiviteter i et mindre antal institutioner, og som kun et fåtal af de KF-ansatte lader til at kende. Derudover findes der små, lokale foretagender, vi ved meget lidt om. Hvor mange af sådanne initiativer, der er lokalforankret i en eller få institutioner, ved vi ikke, da samarbejdet med frivillige organisationer i Kriminalforsorgen ikke er formaliseret, og derfor kan indgås på forskellige niveauer (Olesen, upubliceret).

\section{Programmer og udækkede behov}

De frivillige organisationers resocialiserende programmer i Kriminalforsorgen består af en bred vifte af indsatser og aktiviteter, som bl.a. inkluderer besøg og andre former for socialt samvær, mentorer, uddannelses- og beskæftigelsesstøtte, retshjælp, økonomi- og gældsrådgivning, familiestøtte til pårørende og børn, kreative aktiviteter, udgang/frigang til kulturelle/sociale aktiviteter og terapi. Nogle organisationer tilbyder flere programmer, mens andre fokuserer på et enkelt. Enkelte organisationer har en kirkelig social profil. Det var kun muligt at identificere én organisation, der specifikt gjorde en indsats for at støtte udenlandske indsatte, og ligeledes én organisation der stod til rådighed for indsatte/prøveløsladte fra Grønland. Et program specifikt rettet mod indsatte/prøveløsladte med muslimsk baggrund blev ikke identificeret.

Både KF-ansatte og frivillig-ansvarlige tilkendegiver, at der er et stort behov for de frivillige i Kriminalforsorgens institutioner: »Det er megagodt, de [frivillige] kommer ind med deres hjælp, så vi kan supplere hinanden, eller vi reelt kan bruge dem lidt også som en hotline« (ansat, fængsel). De frivillig-ansvarlige bemærker dog, at der er stor forskel på, hvornår de indsatte har mest brug for deres programmer. I arresthuse og lukkede fængsler har de frihedsberøvede ifølge de frivillig-ansvarlige et stort behov for støtte og kontakt. Begge institutionsformer bærer præg af, at sikkerheden er højt prioriteret, og fremtidsudsigterne til at vende tilbage til samfundet er uvisse eller lange. De indsatte i de åbne fængsler har derimod flere aktiviteter at vælge imellem og generelt større frihed til at benytte sig af disse. Det er også i de åbne fængsler og gerne i perioden op til løsladelsestidspunktet, at de frivillig-ansvarlige ser det største behov for fx retshjælp, mentorer og gældsrådgivning.

Et forbedringsforslag, som afspejler et udækket behov blandt de indsatte/ prøveløsladte, går på at trække på det lokale foreningsliv i fængslerne og under udslusning fra fængsel til samfund: »Lad os nu lave noget sport, nogle 
bands, noget aftenskole, prøv at hør her, de [indsatte] keder sig" (ansat, områdekontor). Et andet udækket behov, omhandler manglende kognitiv støtte og terapeutiske programmer til de indsatte, så de kan aflære gamle negative tankemønstre og tillære sig nye positive. Derudover bemærker mange frivillig-ansvarlige, at der er et stort behov for at støtte de korttidsdømte, som grundet Kriminalforsorgens risiko- og behovsvurderingsredskab (LS/RNR) ikke får den fornødne hjælp, som de vurderes at have brug for. En frivillig-ansvarlig bemærker hertil:

Jeg tror egentlig, Kriminalforsorgen ser der er et behov, de har bare ikke muligheden. Altså man kan sige, der er nogle overordnede retningslinjer indenfor Kriminalforsorgen i forhold til, hvordan de skal screene [de indsatte], og hvordan de skal bruge deres mentorordning i dag, men der er nogle indsatte, som ikke falder i den kategori, som jeg ser har et behov for støtte, og der siger jeg ikke, at det er Kriminalforsorgen, der overser dem, for det ser de ansatte derude jo også, men der er ikke lige det rigtige tilbud i deres skuffe.

Den frivillig-ansvarlige omtaler i ovenstående en generel problematik, der går på, at det faglige skøn blandt de KF-ansatte i overvejende grad er blevet erstattet af mere standardiserede tilgange, som gør det vanskeligt at nå de indsatte/prøveløsladte, der har behov for hjælp (Olesen, upubliceret).

\section{De frivilliges bidrag}

I udgangspunktet møder de frivillige ikke egentlig modstand i Kriminalforsorgens institutioner. Interviewene belyser derimod, at der er en udbredt anerkendelse af, at de frivillige gør et godt stykke arbejde, og at de har nogle faglige kompetencer, som de KF-ansatte ikke selv besidder. De KF-ansatte beskriver tre overordnede bidrag fra de frivillige, som de tillægger stor betydning. Det ene relaterer sig til livet i fængsel, hvor de frivillige medvirker til, at de indsatte »får et break i hverdagen«, »virker som ventil for frustration«, »giver et pusterum«, »skaber små lyspunkter« og »tager noget af samfundet med ind i fængslerne«. Overordnet påpeger de KF-ansatte, at de frivillige på den måde bidrager til normalisering i fængslerne. Det andet overordnede bidrag fra de frivillige relaterer sig til brobygning, idet de KF-ansatte fremhæver, at de frivillige »skaber et tilhørsforhold udenfor« og »er gode til at gå ved siden af den prøveløsladte«. Det tredje overordnede bidrag går på tværs af afsoning og løsladelse og handler om, at de frivillige »hjælper med de små ting", »hjælper med de praktiske ting", og "gør livet lidt nemmere at leve«. Disse tre overordnede bidrag, som de KF-ansatte belyser, stemmer nogenlunde overens med det, de frivillige-ansvarlige selv betegner som deres styrker.

Datamaterialet vidner også om, at de KF-ansatte i nogle situationer betragter de frivillige organisationers programmer som mere end blot et supplement 
til de programmer, som Kriminalforsorgen selv eller en anden offentlig myndighed kan bidrage med. En KiF-medarbejder kommer med et eksempel:

Lad os sige, vi sidder med en gut, der har været inde at sidde og har ondt i livet. Konen skred, og børnene vil ikke snakke med ham, alle de der ting, hvor vi ved, at det kommunale system bare ikke altid synes, at det er noget, de heller skal finansiere. Du kan godt få en henvisning fra en læge, men der er seks måneders ventetid. Der er det, vi kan sige, jamen hvis du tager ind til Cafe Exit og klager din nød der, så har de faktisk psykologer tilknyttet, som ovenikøbet er godt klædt på til de problematikker, som du måske har pga. din afsoning.

De frivillige organisationers programmer bliver således af nogle KF-ansatte betragtet som en reel konkurrent til de offentlige tilbud, fordi de frivillige er tilgængelige, fleksible og har et specifikt kendskab til målgruppen.

Der er enkelte eksempler i datamaterialet, hvor de KF-ansatte påpeger, at nogle frivillige fremstår en anelse naive eller umodne: »Dem der kommer i fængslerne, de giver måske lidt for meget, altså de har svært ved at sætte grænserne for, hvad giver man, og hvad giver man ikke« (ansat, fængsel). I tråd hermed bliver det også i enkelte tilfælde beskrevet, hvordan de frivillige går ud over deres opgaveportefølje og kommer for tæt på og bliver for kritiske over for de KF-ansattes tilgang:

Der er lige nogle gange, hvor man må sige [hoster bestemt]: 'I skal ikke rende med den opgave der'. Så har en indsat siddet og fyldt sådan en ung studerende med alt muligt, og så syntes hun jo lige, at hun skal spørge til, om det virkelig kan være rigtigt, at han ikke kan få udgang, og der må vi jo sige: ' $\varnothing \mathrm{h}$ ja, det kan virkelig være rigtigt, fordi vi har fulgt reglerne, men derudover så var det jo heller ikke din opgave'. Altså, der er de indsatte jo også smaddergode ikke, så kommer der en og spørger: 'Har du ellers nogle udfordringer?' Og så vælter det jo ud af dem. Så der skal man lige være sådan lidt skarp nogle gange: 'Vi er meget taknemmelig for, at I kommer og snakker med de indsatte, men I skal snakke med dem om jeres opgave.' (...) Vi har ikke brug for en vagthund.

I lighed med de KF-ansattes udtalelser om enkelte frivillige, så beretter enkelte frivillig-ansvarlige, at de oplever, at de KF-ansatte ikke bryder sig om at »blive kigget efter i sømmene«, og de derfor besværliggør samarbejdet.

\section{Fremgangsmåder}

Programmerne kan opdeles i brobyggende eller tidsbegrænsede. Hovedparten af organisationerne har et brobyggende sigte, hvilket vil sige, at de i bogstavelig forstand bestræber sig på at danne bro mellem fængsel og det øvrige samfund ved at bevare kontakten til den indsatte og fastholde den indsatte i programmet i forbindelse med (prøve)løsladelse. I de tidsbegrænsede programmer er der indbygget et tydeligt tidsperspektiv, som rammesætter dem. Det eksemplificerer en frivillig-ansvarlig for et kreativt 
program bl.a. ved at bemærke: „Smykkerne skal helst laves samme dag [vi er der], for de [frivillige] kommer kun hver 14. dag i det ene fængsel og en gang om måneden i det andet, og så kan mange af dem [de indsatte] jo være væk igen." Dette tidsperspektiv bygger på, at der i Danmark bliver afsagt mange ubetingede fængselsdomme på under fire måneder (Kriminalforsorgen, side 9), hvilket begrænser såvel KF-ansattes som frivilliges tid med den indsatte. På tilsvarende vis spiller tidsperspektivet en rolle for de frivillige, der kører programmer, som ikke er brobyggende, men dog strækker sig over længere tid. En frivillig-ansvarlig for et uddannelsesstøttende program eksemplificerer, hvordan tiden spiller en afgørende rolle i deres arbejde, da de kun kan samarbejde med de fængsler »hvor dem, der sidder der, har en forholdsvis lang dom. Altså hvis du skal kunne tage en HF, mens du sidder inde, så er det jo kun nogle fængsler, der giver mening [at samarbejde med].« De frivillige organisationers programmer skal derfor sammentænkes med de afsoningsforløb, som de indsatte har.

Tiden spiller også på andre måder en rolle for de frivillige, da flere ser tiden som noget, de i modsætning til de KF-ansatte ikke er begrænset af, men snarere betragter som en ressource, de kan investere i de indsatte/ prøveløsladte. Denne ressource bliver også identificeret af de KF-ansatte og beskrevet som en afgørende faktor i de frivilliges arbejde: »De frivillige hænger sig ikke så meget i klokken. Selvom tidspunktet er skævt, hvis der er brug for dem, så stiller de op, de indsatte kommer ikke til en lukket dør, ligesom de kan opleve i det offentlige« (ansat, områdekontor). Tid som de frivilliges investeringsmulighed i de indsatte udfordres dog af, at der kun er afsat en begrænset tidsramme til de frivillige organisationers programmer i fængslerne.

\section{Relationsarbejde}

Organisationerne anvender forskellige strategier til at skabe den indledende kontakt mellem indsat og frivillig. Nogle tager afsæt i udgående arbejde, hvor den frivillige aktivt opsøger den indsatte i fængslet, hvilket dog kræver, at der er KF-ansatte, der kan hjælpe med at formidle den første kontakt. Andre er afhængige af, at den indsatte selv kontakter organisationen eller at andre, eksempelvis KF-ansatte, formidler kontakten, hvilket i begge tilfælde kræver et forudgående kendskab til organisationen.

Særligt relationsarbejdet bliver fremhævet som et område, hvor de frivillige både har kompetencer, men også et bedre udgangspunkt, end de KF-ansatte. De KF-ansatte pointerer nemlig, at de i modsætning til de uafhængige frivillige repræsenterer 'systemet': "vores opgave er jo at fuldbyrde straf, det er det øverste« (ansat, fængsel), og det vanskeliggør relationsarbejdet med de indsatte/prøveløsladte, som ofte møder dem med mistillid og systemfjendskhed (se også Minke; Billund). Dobbeltsigtet på sikkerhed og resocialisering, som 
de KF-ansatte har, kendetegner på sin vis også relationsarbejdet. Relationsarbejde kan for de KF-ansatte nemlig både bidrage med støtte og hjælp til den enkelte indsatte/prøveløsladte og til at understøtte den dynamiske sikkerhed i fængslerne (Billund). Dette dobbeltsigte er de frivillige fri for. De kan tilgå de indsatte/prøveløsladte med en mere åben og ligeværdig dialog, hvilket er altafgørende, når det handler om opbygning af en tillidsfuld relation: »Det gør en kæmpe forskel, at det ikke er nogen, der er, hvad skal man sige, der er født og opvokset i Kriminalforsorgen. Som kommer ind som et frisk pust og ikke har den her fordom om kriminelle, som meget nemt kan præge det herinde, hvor vi kender historierne, og vi har jo hørt dem masser af gange« (ansat, områdekontor).

De interviewede KF-ansatte vil dog gerne investere mere af deres tid i relationsarbejdet, og flere af dem påpeger, at »vi har kompetencerne, men det bliver bare ikke prioriteret nok« (ansat, fængsel). Personalegrupperne giver enstemmigt udtryk for, at de har en presset arbejdsdag, hvor fangepopulationen er blevet hårdere, og hvor opgaver med et administrativt og sikkerhedsmæssigt sigte kommer i første række. En KiF-medarbejder bemærker hertil: „Vi har en del lovbundne eller vejledningsbundne opgaver, altså hvordan vi skal arbejde, altså ud fra hvilke modeller. Vi har simpelthen fået nogle andre koncepter at arbejde ud fra, mere fokus på risiko og det kriminalpræventive og meget mindre tid til den her gode gammeldags socialfaglige funktion." En anden KiF-medarbejder påpeger, hvordan de nye arbejdsmetoder påvirker deres relation til de prøveløsladte: „Vi mister noget i relationsarbejdet, når vi lader de frivillige udføre det opfølgende arbejde med klienterne.« Ingen af de KF-ansatte udtrykker en negativ holdning til relationsarbejde eller resocialiserende aktiviteter, men hovedparten bemærker, at der er en gruppe af fængselsbetjente på deres arbejdsplads, som af forskellige grunde ikke støtter op om relationsarbejde og resocialiserende aktiviteter. De frivilligansvarlige beretter ligeledes om, hvordan de oplever, at mange KF-ansatte rigtig gerne vil bidrage til det resocialiserende arbejde, men de lader til at være tynget af tidspres og et dårligt arbejdsmiljø.

\section{Samarbejde: Et ulige magtforhold på en ressourceknap arbejdsplads}

Interviewene belyser, at der er tale om mange forskellige slags samarbejder og også samarbejdsvanskeligheder alt afhængig af, hvilken institutionstype de frivillige organisationer samarbejder med (Olesen, upubliceret). En frivillig-ansvarlig pointerer, at der er »stor forskel på at arbejde i de åbne og lukkede fængsler. Ikke nødvendigvis personalets velvillighed, men det er meget nemmere i de åbne [fængsler]." I tråd hermed påpeger en anden frivillig-ansvarlig, at i de lukkede fængsler og i de lukkede afdelinger »er det sværere for de frivillige. Kommunikationen med de indsatte er mere besværliggjort, og det 
er mere bøvlet for dem at komme ind." Uafhængigt af hvilken institutionstype de frivillige organisationer samarbejder med, så har personalegruppen og sikkerhedsforanstaltninger en stor indvirkning på samarbejdet.

\section{Gatekeeper til målgruppen}

Da de indsatte selvsagt er frihedsberøvede, betyder det, at de ikke uden videre kan få udgang til at aflægge organisationerne et visit. De fleste af de organisationer, der indgår i dette studie, besøger jævnligt et eller flere fængsler, men de har ikke deres daglige gang i fængslerne. Ofte kører de langt for at nå til fængslerne, hvor der kun er afsat begrænset tid til samtaler eller aktiviteter. Et fåtal af de opsøgende frivillige kan frit gå rundt på fængselsafdelinger og rette direkte henvendelse til de indsatte, mens et andet fåtal har et lokale, hvor de indsatte kan træffe dem på bestemte dage. Hovedparten af de frivillige bliver dog tildelt et lokale ved deres ankomst, hvor de indsatte, som har booket en tid, på skift bliver fulgt ind af personalet. Det opsøgende element og den smidighed, som ellers kendetegner frivilligt arbejde (La Cour), er derfor ganske begrænset i fængslerne, og de frivilliges såkaldte kontortider og krav om mødebooking kommer hurtigt til at minde om de krav, som offentlige myndigheder stiller. Denne organisering betyder, at organisationerne må sætte deres lid til, at fængselspersonalet vil fungere som ambassadører for deres programmer, orientere de indsatte om, hvornår de kommer, booke mødetider, sikkerhedsgodkende de frivillige, stå for sikkerhed under fængselsbesøget og tilmed eskortere de indsatte til og fra mødet/aktiviteten. Der er derfor fysiske barrierer, der gør samarbejdet mindre smidigt, og som samtidig positionerer fængselspersonalet som vigtige gatekeepere mellem de indsatte og frivillige. En KF-ansat i et arresthus eksemplificerer:

Der er altid en sikkerhedsproblematik forbundet med det: 'Kan vi give en gældsrådgiver nøgler? Nej, det ville vi ikke gøre.' Så skal de følges rundt af fx en socialrådgiver. Så kan man sige: 'Skal vi holde det nede i vores besøgsafdeling? Nej, for så optager de besøgsrum for pårørende, der skal ind og besøge.' Så der er nogle forskellige ting i det. Der kan være sikkerhedsmæssige udfordringer, og der kan være ressourcemæssige udfordringer (...) der er en masse praktiske ting, når man skal have nogen ind, der ikke hører til.

Det frivillige arbejde i fængslerne er således i tæt konkurrence om de knappe ressourcer i Kriminalforsorgen og indgår dermed i den overordnede prioritering af ressourcefordeling og opgaveløsning. Ud fra et administrativt og sikkerhedsmæssigt perspektiv bliver det frivillige arbejde således henregnet som ressourcekrævende fremfor ressourcefrigivende. Afhængighedsforholdet fremgår helt åbenlyst af interviewene, idet de frivillige organisationers eksistensgrundlag ofte afhænger af Kriminalforsorgens velvilje til at samarbejde. De frivillig-ansvarlige affinder sig derfor også med »at sluge rigtig mange kameler« 
og accepterer, at »vi skal imødekomme dem, og det skal passe præcist ind i hvert fængsels individuelle hverdag«. Men nogle af de frivillig-ansvarlige understreger også: »Der er ikke nogle egentlige udfordringer med fængselspersonalet, men der er selvfølgelig alle de udfordringer, som fængselsrammerne skaber.« Den afhængighed som de frivillig-ansvarlige i interviewene giver udtryk for at have til Kriminalforsorgen, fremstår ikke som værende gensidig, selvom de KF-ansatte generelt sætter pris på de frivilliges arbejde.

De KF-ansatte fremhæver især de frivilliges brobyggende arbejde mellem fængsel og samfund: „Vi kan bruge de frivillige til skift. De er rigtig gode til skift. Og vi ved jo at skift, det er rigtig svært, og der kan man [de løsladte] nemt falde ned mellem stolene (ansat, områdekontor). Parallelt med de mange roser beretter de frivillig-ansvarlige om, at de finder det ganske udfordrende at kvalitetssikre eller færdiggøre deres arbejde, når de KF-ansatte, trods underskrevne samtykkeerklæringer, ikke videreformidler vigtig information om de indsatte/prøveløsladte. To frivillig-ansvarlige beskriver nogle gennemgående udfordringer afledt af mangelfuld kommunikation, hvor de indsatte/ prøveløsladte bliver pålagt et stort ansvar, hvis deres samarbejde med en frivillig organisation skal fortsætte efter en forflyttelse eller prøveløsladelse:

Den der lukkethed, den er virkelig svær. Vi bevæger os ind i en lukket verden, hvor sikkerhed fylder alt. Og det kan være vanskeligt, hvis vi har en deltager, som lige pludselig bliver overflyttet til et andet fængsel, og så mister vi kontakten, medmindre vi har husket at blive skrevet ind i den indsattes handleplan med den frivilliges telefonnummer, og har nået at give den indsatte besked om, at hvis de pludselig bliver overflyttet, så er det altså din egen opgave at ringe og give besked, for ellers må vi ikke få at vide, hvor du er.

De løslader dem bare, også uden at fortælle os det. Det er altid os, der må være de opsøgende [op til en løsladelse], selvom de [ansatte] ved, der er frivillige inde over. Det er altid os, der ringer og gør osv.

Interviewene belyser en modsætning i, at de KF-ansatte (på koordinator- og ledelsesniveau) hylder de frivillige for at være gode til at bygge bro mellem fængsel og samfund, mens udførelsen af de frivilliges programmer indirekte modarbejdes ved manglende koordinering og kommunikation mellem de frivillige og de KF-ansatte. Disse udfordringer er tæt sammenlignelige med de samarbejdsvanskeligheder, som er identificeret i Kriminalforsorgens løsladelsessamarbejde med kommunerne (Petersen).

Det kan udledes, at konteksten, hvori det frivillige arbejde udføres, er rammesættende, ikke blot for de programmer de frivillige tilbyder, men også for samarbejdet med de KF-ansatte. Fokusset på sikkerhed og kontrol i Kriminalforsorgens institutioner betyder, at de frivillige ikke har de samme muligheder for at møde de indsatte med en åben og fleksibel tilgang, som de har i det øvrige samfund. 


\section{Manglende kendskab til de frivillige organisationer}

Med de mange grænseflader og deres fælles målgruppe for øje, er det interessant, at de frivilliges arbejde med få undtagelser bliver italesat af de $\mathrm{KF}$-ansatte, som isolerede tilbud, der ikke rigtig vedkommer dem. KiF-medarbejderne involverer sig derfor kun i meget begrænset omfang, og fængselspersonalet involverer sig nærmest kun, når samarbejdet kræver assistance i form af logistisk eller sikkerhedsmæssig karakter.

Af de KF-ansattes spørgeskemasvar fremstod det tydeligt, at der var et begrænset kendskab til de frivillige organisationer og deres programmer, selvom de frivillige jævnligt færdes i de danske fængsler eller besøger KiF-afdelingerne. De få organisationer, der gentagne gange blev nævnt, var de største organisationer med de mest veletablerede programmer, der bestræber sig på at være tilgængelig for indsatte/prøveløsladte i hele landet. Interviewene med de største organisationer viser, at det har krævet en stor indsats, at få udbredt kendskabet til organisationens program(mer).

Det beskedne kendskab til den ellers brede vifte af frivillige initiativer medfører forskellige problematikker. En af disse er, at især de frivillig-ansvarlige for mindre programmer oplever, at det kan være svært »at skabe en forståelse fra hele fængslet for, hvad det er for en indsats, vi laver, hvem de frivillige er (...). Jeg synes ikke, de [ansatte] er særlig gode til at fortælle om den hjæ/p, vi kan give.« En frivillig-ansvarlig for et mere veletableret program understøtter denne oplevelse ved at påpege, at "selvom vi har sagt, at vi ikke har midler til at løfte projektet, så fortsætter fængslerne alligevel med at henvise til os." Det tyder altså på, at der er en skævvridning i de KF-ansattes henvisningspraksis, fordi de kun kender et fåtal af de programmer, der arbejder med deres målgruppe. De KF-ansatte mangler ganske enkelt et overblik over hvilke organisationer, der kan tilbyde hvad til hvem. En lignende tendens er også identificeret i den internationale litteratur på området (se fx Gojkovic et al.; Mills et al., 2012).

\section{Personbåret samarbejde}

Datamaterialet belyste, at den manglende gensidige afhængighed mellem KF-ansatte og frivillige og de KF-ansattes manglende kendskab til de frivilliges programmer bl.a. betyder, at de frivillig-ansvarlige ofte selv er nødt til at være opsøgende, hvis de ønsker et samarbejde. Det er således op til de frivillig-ansvarlige at finde en vej 'ind' i Kriminalforsorgen og få skabt den fornødne kontakt. Når et samarbejde er etableret, er det op til de frivilligansvarlige at vedligeholde disse samarbejder, hvorfor den personlige kontakt er altafgørende for, om et samarbejde blomstrer eller løber ud i sandet.

Samarbejdet er ikke organisatorisk styret, og rammerne er derfor sjældent tydeligt defineret. De steder, hvor der er skabt gode personlige re- 
lationer mellem frivillig og KF-ansat, er samarbejdet stærkere og mere fleksibelt: „Hvis man har en kontaktperson, der virkelig vil spille med, så er der rigtig meget, der kan lade sig gøre« (frivillig-ansvarlig). Flere af de interviewede, nævner af sig selv specifikke personer, som de samarbejder særlig godt med, og som de mener, at det gode samarbejde også afhænger af: "Når indsatte ringer til os, kan jeg se, at det ofte er fra de steder, hvor vi kender betjentene i forvejen« (frivillig-ansvarlig). ${ }^{4}$ Som tidligere omtalt beretter flere frivillig-ansvarlige om, at det har taget dem meget lang tid at vinde fodfæste i Kriminalforsorgens institutioner, og både KF-ansatte og frivillige fortæller, at rekruttering fra Kriminalforsorgens personalegruppe til frivillighedssektoren kan have visse fordele bl.a. i etableringen af gode samarbejder: "Cafe Exit nyder godt af at have et godt renommé i Kriminalforsorgen, og fx vores præster har en tilknytning til Cafe Exit, lederen af Cafe Exit er tidligere medarbejder i Kriminalforsorgen og sådan noget, der er noget der (...) relationen betyder en del« (ansat, arresthus).

Netop det, at samarbejdet er personbåret, gør det også sårbart, og samarbejdet kan vanskeliggøres eller gå til grunde ved personaleudskiftning. En KF-ansat fortæller, at han på egen opfordring er blevet tovholder på nogle resocialiserende programmer udbudt af frivillige organisationer, fordi han mener, at disse ellers bliver negligeret. Den manglende styring af samarbejdet med de frivillige organisationer problematiserer han således: »Hvis jeg nu mod forventning skulle få et andet job, jamen så ville det her gå tabt. Og det er derfor, at det er vigtigt at få struktureret det [samarbejdet med de frivillige organisationer], gjort det synligt, og beskrevet, hvad der ligger i den her opgave, når man er tovholder for Primus Motor, eller hvad det nu kunne være« (ansat, områdekontor). Den manglende tovholderfunktion af resocialiserende programmer er et generelt kritikpunkt fra både KF-ansatte og frivillig-ansvarlige, der påpeger, at der siden Kriminalforsorgens reorganisering i 2015 ikke har været en tilstrækkelig koordinering af resocialiserende programmer udbudt af frivillige (Olesen, upubliceret).

De ovennævnte forhold bliver ikke blot beskrevet som en ufuldkommen og sårbar tilgang, men medvirker ifølge de frivillig-ansvarlige også til, at de skal levere, når de får adgang til Kriminalforsorgens institutioner: »Hvis vi falder over vores ben inde i fængslerne, så kommer vi ikke ind mere« påpeger en frivillig-ansvarlig. Ud fra den indsamlede empiri, lader det til, at et program kan blive underlagt KF-ansattes individuelle kvalitetsvurderinger, som det kan være svært for de frivillige organisationer at opponere mod: „Nogle steder har de stor fidus til os og andre steder, så har der været et eller andet, en dårlig episode, hvor det kan være svært at få visket tavlen ren, som så gør, at de måske bruger et andet tilbud« (frivillig-ansvarlig). Et egentligt kvalitetssikringssystem af de frivillige organisationers programmer eksisterer dog ikke (se også deleted for referee).

4. Et personbåret samarbejde bliver ligeledes identificeret i evalueringen af Kriminalforsorgens mentorordning (se Nielsen 2017). 


\section{Afrundende bemærkninger}

Datamaterialet vidner om, at der er en udbredt anerkendelse af de frivilliges resocialiserende arbejde i Kriminalforsorgens institutioner, særligt når det gælder relationsarbejde og brobyggende arbejde med de indsatte, hvor de frivilliges en-til-en kommunikation med målgruppen er styrket af deres uafhængighed til Kriminalforsorgen og det offentlige system generelt. Det fremgår ligeledes tydeligt af datamaterialet, at de KF-ansatte betragter de frivilliges tilstedeværelse i fængslerne som et bidrag til normalisering, da de frivillige ikke blot yder konkret hjælp og støtte, men også symbolsk bringer samfundet med ind i den totale institution.

Trods potentiale og velvillighed fra de involverede parter bærer samarbejdet ikke desto mindre præg af at foregå indenfor rammerne af en ubalanceret samarbejdsstruktur i en politisk styret institution med høje sikkerhedskrav. Samarbejdet mellem de frivillige organisationer og Kriminalforsorgen er ikke formaliseret, og de frivillige organisationers bidrag til det resocialiserende arbejde bliver således ikke medregnet som kontinuerlige indsatser og ej heller indtænkt i Kriminalforsorgens strategi. Det frivillige arbejde i Kriminalforsorgen er noget »ekstra« (ansat, direktoratet). Det betyder, at samarbejdet trods positivt outcome kræver tid og mandskab fra en ressourceknap arbejdsplads, hvorfor de KF-ansatte ud fra et administrativt og sikkerhedsmæssigt perspektiv henregner de frivilliges indsats som ressourcekrævende frem for ressourcefrigivende. Set udefra kan samarbejdet mellem Kriminalforsorgen og de frivillige organisationer betragtes som et gensidigt afhængighedsforhold, hvor Kriminalforsorgen nyder godt af de frivilliges resocialiserende programmer, som de ikke selv har kapacitet eller kompetencer til at tilbyde, alt imens de frivillige drager fordel af, at de KF-ansatte henviser de indsatte og prøveløsladte til dem og står for de frivilliges sikkerhed under fængsels- og arrestbesøg. Men interviewene med de involverede parter skildrer snarere en envejsrelation, hvor de frivillige organisationer i overvejende grad har et afhængighedsforhold til Kriminalforsorgen - ikke omvendt. Denne ubalance kommer bl.a. til udtryk ved, at det er de frivillige organisationer, der skal indbyde til samarbejde og dialog, være kompromissøgende og også vedligeholde samarbejdet. De KF-ansatte har et meget beskedent kendskab til de resocialiserende programmer udbudt af frivillige organisationer og en henvisningspraksis, der afspejler deres begrænsede kendskab. Flere af de frivillige programmer hviler derfor alene på personbårne relationer til specifikke engagerede KF-ansatte, hvilket gør programmerne sårbare. På baggrund af datamaterialet kan det udledes, at et øget kendskab til de frivillige organisationer vil kunne styrke den henvisningspraksis, man har i Kriminalforsorgens institutioner.

Det kan af studiet konkluderes, at samarbejdets indhold virker til at imødekomme flere af de behov, der findes blandt målgruppen, og de KF-ansatte, frivillige og indsatte/prøveløsladte i fællesskab med fordel kan definere bestemte indholdsmæssige mål for det fremtidige samarbejde. Den store hæmsko for samarbejdet er imidlertid dets struktur og organisering (og i nogen 
grad kulturen hvori samarbejdet udføres). Hvis de identificerede problemstillinger skal udbedres, kræver det en nytænkning af samarbejdet mellem Kriminalforsorgen og de frivillige organisationer. Det er svært at se en sådan nytænkning opstå uden en forbedring af de KF-ansattes arbejdsvilkår og en reel politisk prioritering af den frivillige sektors bidrag til det resocialiserende arbejde i Kriminalforsorgen - hvor der er øje for at bevare de frivillige organisationers uafhængighed til den offentlige sektor.

Kontaktoplysninger

Annette Olesen: aol@socsci.aau.dk

Anders Brinck Rosenholm: asbrinck@gmail.com

\section{Litteratur}

Abrams, L.S., Moreno, L. \& Harrikari, T. (2019). »The Voluntary Sector Role in Youth and Young Adult Justice Services: A Comparative Case Study of Finland and England/Wales." Youth Justice 19 (3): 278-298.

https://doi.org/10.1177/1473225419886932

Armstrong, S. (2002). »Punishing Not-For-Profit: Implications of Nonprofit Privatization in Juvenile Punishment.« Punishment and Society 4: 345-68.

https://doi.org/10.1177/146247402400426789

Berger, N. P. et al. (2020). »Ny model for modtagelse af indsatte i danske fængsler Procesevaluering af implementeringen.« VIVE.

Billund, L. (2016). Arbejde og samarbejde i tvangsbårne relationer: Et relationsteoretisk perspektiv på fængselsbetjentfaget. Aalborg Universitetsforlag. Ph.d.-serien for Det Humanistiske Fakultet, Aalborg Universitet.

Bryans, S. Martin, C. \& Walker, R. (2002). »The road ahead: Issues and strategies for future joint working." In Prisons and the Voluntary Sector, edited by Bryans, S., Martin, C., \& Walker, R., 162-173. Winchester: Waterside Press.

Cohen, M.L. (2009). „Choral Singing and Prison Inmates: Influences of Performing in a Prison Choir.« Journal of Correctional Education 60: 52-65.

Cohen, S. (1985). Visions of Social Control: Crime, Punishment and Classification. Polity Press.

Direktoratet for Kriminalforsorgen (1998). Kriminalforsorgens Principprogram.

Duwe, G. \& Johnson, B.R. (2016). »The effects of prison visits from community volunteers on offender recidivism. The Prison Journal 96 (2): 279-303.

https://doi.org/10.1177/0032885515618468

Fængselsforbundet (2020). Fængselsfunktionæren 5, oktober 2020.

Gibbs, G. (2009). Analyzing Qualitative Data. London: Sage.

Gojkovic, D., Meek, R. \& Mills, A. (2011). Offender Engagement with Third Sector Organisations: A National Prison-based Survey. Third Sector Research Centre, Working Paper 61.

Helminen, M. (2016). »Nordic and Scottish civil society organizations working with offenders and the effects of service delivery: Is pursuing mission impossible whilst bidding contracts?« The Howard Journal of Crime and Justice 55 (1/2): 73-93.

https://doi.org/10.1111/hojo.12152

Helminen, M. \& Mills, A. (2019). »Exploring autonomy in the Finnish and New Zealand penal voluntary sectors: The relevance of marketisation and criminal justice policy environments."The Howard Journal of Crime and Justice 58: 404-429.

https://doi.org/10.1111/hojo.12319 
Henriksen, L.S. \& Bundesen, P. (2004). »The moving frontier in Denmark: Voluntary-state relationships since 1850.« Journal of Social Policy 33 (4): 605-615.

https://doi.org/10.1017/S0047279404008025

Henriksen, L.S., Smith, S.R. \& Zimmer, A. (2015). „Welfare mix and hybridity. Flexible adjustments to changed environments. Introduction to the special issue.« Voluntas: International Journal of Voluntary and Nonprofit Organizations 26 (5): 1591-1600. https://doi.org/10.1007/s11266-015-9622-y

Hucklesby, A. \& Worrall, J. (2007). »The voluntary sector and prisoners' resettlement.« In Prisoner Resettlement: Policy and Practice, edited by Hucklesby, A. \& Hagley-Dickinson, L., 174-196. Cullompton: Willan Publishing.

Kriminalforsorgen. 2019. „Statistik 2019." Kriminalforsorgen,

Larsen, B.Ø., Pejtersen, J.H., Bom, L.H., Hansen, H., Berger, N.P., Jørgensen, T.S. \& Barkholt, K. (2020). Psykiske belastningsreaktioner hos polititjenestemænd og fængselsbetjente. VIVE - Viden til Velfærd, Det Nationale Forsknings- og Analysecenter for Velfærd.

Lewis, S., Maguire, M., Raynor, P., Vanstone, M., \& Vennard, J. (2007). „What Works in Resettlement? Findings from Seven Pathfinders for Short-term Prisoners in England and Wales." Criminology and Criminal Justice, 7: 33-53.

https://doi.org/10.1177/1748895807072475

Liebling, A., Tait, S., Stiles, A., Durie, L. \& Harvey, J. (2005). An Evaluation of the Safer Locals Programme, Cambridge Institute of Criminology Prisons Research Centre.

Lippke, R.L. (2003). »Prisoner Access to Recreation, Entertainment and Diversion. Punishment and Society 5: 33-52. https://doi.org/10.1177/1462474503005001045

Maguire, M. (2012). »Response 1: Big Society, the voluntary sector and the marketisation of criminal justice.« Criminology and Criminal Justice 12 (5): 483-505.

https://doi.org/10.1177/1748895812459002

Mills, A., Meek, R. \& Gojkovic, D. (2012) »Partners, guest or competitors: Relationships between criminal justice and third sector staff in prison. Probation Journal 59 (4): 391-405. https://doi.org/10.1177/0264550512458475

Mills, A., Meek, R. \& Gojkovic, D. (2011). „Exploring the relationship between the voluntary sector and the state in criminal justice.« Voluntary Sector Review 2 (2): 193-211. https://doi.org/10.1332/204080511X583850

Minke, L.K. (2012). Fængslets indre liv. København: DJØF/Jurist- og Økonomforbundets Forlag.

Neuberger, B. (2009). Volunteering Across the Criminal Justice System. London: The Cabinet Office

Nielsen M.M. (2017). Evaluering af mentorordningen. Kriminalforsorgen.

Olesen, A. (2021). »lkke-formaliserede samarbejder mellem frivillighedssektoren og Kriminalforsorgen. (Upubliceret). Under udarbejdelse for peer review med henblik på publicering i et kommende nummer af NTfK.

Petersen, P.G. (2016). Kriminalforsorgens samarbejde med kommunerne. Analyse af myndighedssamarbejdet mellem Kriminalforsorgen og kommunerne. Direktoratet for Kriminalforsorgen.

Ramsbøl, H. \& Rasmussen, N. (2009). Projekt god løsladelse. Servicestyrelsen.

Rigsrevisionen (2011). Beretning om Kriminalforsorgens initiativer til forebyggelse af dømtes tilbagefald til kriminalitet. Statsrevisorerne.

Rönneling, A. \& Lund-Sørensen, N. (2014). Hvad er planen? - En kvalitativ undersøgelse af indholdet i Kriminalforsorgens handleplaner. Kriminalforsorgen.

Rönneling, A., Lund-Sørensen, N. \& Bak, B. (2013). Hvordan og hvor meget? En kvantitativ undersøgelse af handleplansarbejdet i Kriminalforsorgen. Kriminalforsorgen.

Robinson, G. \& Crow, I. (2009). Offender Rehabilitation: Theory, Research and Practice. London: SAGE Publications Ltd.

Storgaard, A., Fridhov, I. M., Persson, A., Svensson, K., \& Ramsbøl, H. (2014). Løsladelse. Nordisk Samarbejdsråd for Kriminologi. 
Tomczak, P.J. (2017a). The Penal Voluntary Sector. London: Routledge. https://doi.org/10.4324/9781315641423

Tomczak, P.J. (2017b). »The Voluntary Sector and the Mandatory Statutory Supervision Requirement: Expanding the Carceral Net.« British Journal of Criminology 57: 152-171. https://doi.org/10.1093/bjc/azv091

Tomczak, P.J. \& Albertson, K.E. (2016). »Prisoner relationships with voluntary sector practitioners.«The Howard Journal of Crime and Justice 55 (1-2): 57-72.

https://doi.org/10.1111/hojo.12164

\section{Love og cirkulærer}

CIR1H nr. 9554 af 19. juni 2017 om udarbejdelse af handleplaner i Kriminalforsorgen.

Lbk. nr. 1333 af 9. december 2019 af lov om fuldbyrdelse af straf m.v. 